www.jmscr.igmpublication.org

Impact Factor 5.244

Index Copernicus Value: 83.27

ISSN (e)-2347-176x ISSN (p) 2455-0450

crossref DOI: _http://dx.doi.org/10.18535/jmscr/v4i10.27

Journal Of Medical Science And Clinical Research

\title{
Prevalence of Asymptomatic Bacteriuria in Pregnancy and Its Outcome
}

\author{
Authors \\ Dr Sonal Sahni ${ }^{1}$, Dr Kirti Patel ${ }^{2}$, Dr Archana G Singh ${ }^{3}$ \\ ${ }^{1}$ Assistant Prof, Dept of Obstetrics \& Gynaecology NSCB Medical College Jabalpur, Madhya Pradesh \\ ${ }^{2}$ Senior Resident, Dept of Obsterics \& Gynaecology NSCB Medical College Jabalpur, Madhya Pradesh \\ ${ }^{3}$ Associate Prof, NSCB Medical College Jabalpur, Madhya Pradesh INDIA
}

\begin{abstract}
Background-Urinary tract infections are disease processes with short and long term implications especially in pregnant females. Adequate understanding, routine screening and timely initiation of therapy may play a key role in reducing the disease burden of complicated $U T T^{s}$ during pregnancy.

Material and Methods-This was a Prospective study, conducted on 401 pregnant females. The pregnant women were taught to collect the urine sample by aseptic technique which was then submitted to semi quantitative culture method. They were followed up till delivery to find impact of bacteriuria on outcome.

Result -Significant bacteriuria was present in $10.22 \%$ cases. About $89.78 \%$ sample were found sterile. The most common etiological agents were, E. Coli followed by Klebsiella and Pseudomonas. Regarding maternal complications, out of 41 positive cases; 8 cases developed pre-eclampsia, 8 cases had premature rupture of membrane and 3 cases developed UTI.

Conclusion-Asymptomatic bacteriuria is a common occurence which should be diagnosed and treated in early pregnancy to prevent its adverse effects on pregnancy.

Key Words-Asymptomatic bacteriuria,UTI, Urine culture.
\end{abstract}

\section{Introduction-}

Urinary tract infections (UTI) are one of the commonest infection in antenatal women. Asymptomatic bacteriuria is one of the clinical manifestation of UTI. It is defined as persistent and actively multiplying bacteria in significant numbers $\left[10^{5} \mathrm{CFU} / \mathrm{ml}\right]$ without any obvious symptoms, it is also known as Covert bacteriuria.

The term asymptomatic bacteriuria of pregnancy refers to presence of positive urine culture $\left[10^{5}\right.$ $\mathrm{CFU} / \mathrm{ml}]$ in an asymptomatic pregnant female. The pregnant females are two times more susceptible than non- pregnant females of same age group due to occurrence of following changes in pregnancy.
1. Dilatation of renal calyces and ureters which leads urinary stasis [due to progesterone induced relaxation of muscular layer]

2. Relaxation of vesico-ureteric junction leads to reflux of urine from bladder to ureter and later upto renal pelvis.

3. Increased urinary contents of glucose and aminoacids which favours bacterial growth.

4. The immunosuppression of pregnancy (mucosal IL-6 levels and serum antibody response to E.coli antigens reported to be lower in pregnant women.) 
5. Various studies, in India, prevalence of asymptomatic bacteriuria was found between $5 \%$ to $12 \%$, while studies from west it is between $2 \%$ to $7 \%$.

Gold standard investigation for detection of asymptomatic bacteriuria is urine culture. Therefore urine culture at $1^{\text {st }}$ antenatal visit irrespective of gestational age should be considered as a screening test of choice. Detection of asymptomatic bacteriuria during pregnancy is important as subsequently, it may lead to symptomatic infection during pregnancy in $25 \%$ women and various maternal complications like anemia, pre-eclamsia, pre-term labour, premature rupture of membrane, chronic kidney infection, LBW etc.

\section{Material and Methods}

The study was conducted from $1^{\text {st }}$ June 2013 to $31^{\text {st }}$ October 2014. 401 asymptomatic pregnant females, at their $1^{\text {st }}$ visit antenatal visit in OPD, were briefed about the study. Consenting women were counselled regarding method of collection of clean catch mid stream urine sample. The samples were immediately transferred and processed within 2 hours of collection and were subjected to semi-quantitative culture method. Identification of isolates were done by gram staining, motility test, catalase test, coagulase test and routine biochemical test. The growth was interpreteted as sterile if no growth obtained, significant if growth obtained was confluent or the number of colonies correspond to $10^{5}$, colony forming units [CFU] per ml. If colony count less than $10^{5} \mathrm{CFU}$ per ml reported as insignificant.

Follow up of the patients with significant urine culture was done two weeks after completion of treatment, then 12 weekly up to delivery to find impact of asymptomatic bacteriuria on maternal and perinatal outcome.
Follow up of patients with sterile urine culture was done 12 weekly up to delivery.

\section{Results}

Out of 401 asymptomatic pregnant women screened, significant bacteriuria was found in 41 [10.22\%] cases (Table no 1). As per sociodemographic profile (Table no 2) $11.5 \%$ reported in age group between $21-25$ years. $61 \%$ of total positive subjects were booked and belonged to urban background. With respect to socioeconomic status $48.8 \%, 46.3 \%$ and $4.9 \%$ positive cases were belongs to low, middle and upper class respectively. According to parity (table no 3 ) out of 41 positive cases, 19[46.3\%] were nullipara and $13[31.7 \%]$ primipara, $7[17.1 \%]$ was second para and only $2[4.9 \%$ ] were multipara. As per trimester of pregnancy incidence was $29.3 \%$ in $1^{\text {st }}$ trimester, $19.5 \%$ in $2^{\text {nd }}$ trimester and $21(51.2 \%$ ) found positive in $3^{\text {rd }}$ trimester (Table no 3 ) of pregnancy.

The commonest isolate detected in urine culture(table no 4) was E.coli $(75.61 \%)$ cases followed by Klebsiella (14.63\%) and Pseudomonas $(9.76 \%)$ cases.

Among all isolates highest sensitivity was found for Amikacin 58.1\% Ecoli, 66.7\% Klebsiella and $50 \%$ Pseudomonas was found sensitive to Amikacin. 26 women delivered vaginally, 8 cases delivered by caesarean section and 7 cases lost to follow up (Table no 5). Regarding maternal complications, 8 patients developed preeclampsia, one case of anemia and pre-eclampsia both, 8 cases had premature rupture of membrane and 3 cases developed UTI (Table no.6. Premature birth(6 cases), low birth weight( 2 cases), intrauterine growth restriction and intra-uterine death (1 each) and early onset septicemia(2), were fetal complications (Table no 7).

Table no 1- Prevalence of Asymptomatic Bacteriuria

\begin{tabular}{|l|c|c|c|}
\hline Culture & Cases & Percentage & $95 \%$ CI \\
\hline SterilE & 360 & $89.78 \%$ & $86.39-92.56 \%$ \\
\hline Positive & 41 & $10.22 \%$ & $7.44 \%-13.61 \%$ \\
\hline Total & 401 & $100 \%$ & \\
\hline
\end{tabular}


Table no 2 Sociodemographic profile

\begin{tabular}{|l|c|c|c|c|}
\hline \multirow{2}{*}{ Age } & \multicolumn{4}{|c|}{ Culture } \\
\cline { 2 - 5 } & \multicolumn{2}{|c|}{ Sterile } & \multicolumn{2}{c|}{ Positive } \\
\cline { 2 - 5 } & Cases & Percentage & Cases & Percentage \% \\
\hline <=20 years & 57 & $91.9 \%$ & 5 & $8.1 \%$ \\
\hline $21-25$ years & 192 & $88.5 \%$ & 25 & $11.5 \%$ \\
\hline $26-30$ years & 93 & $90.3 \%$ & 10 & $9.7 \%$ \\
\hline 31-40 years & 18 & $94.7 \%$ & 1 & $5.3 \%$ \\
\hline Booking status & & & & \\
\hline Booked & 214 & $59.4 \%$ & 25 & $61 . \%$ \\
\hline Un Booked & 146 & $40.6 \%$ & 16 & $39.0 \%$ \\
\hline Locality & & & & \\
\hline Rural & 178 & $49.4 \%$ & 16 & $39 \%$ \\
\hline Urban & 182 & $50.6 \%$ & 25 & $61.0 \%$ \\
\hline Socioeconomic status & & & & \\
\hline Low & 236 & $65.6 \%$ & 20 & $48.8 \%$ \\
\hline Middle & 120 & $33.3 \%$ & 19 & $46.3 \%$ \\
\hline Upper & 4 & $1.2 \%$ & 2 & $4.9 \%$ \\
\hline
\end{tabular}

Table 3 Prevalence Rate With Respect To Parity And Trimester

\begin{tabular}{|c|c|c|c|c|c|c|}
\hline \multirow[t]{3}{*}{ Parity } & \multicolumn{4}{|c|}{ Culture } & \multirow{2}{*}{\multicolumn{2}{|c|}{ Total }} \\
\hline & \multicolumn{2}{|c|}{ Sterile } & \multicolumn{2}{|c|}{ Positive } & & \\
\hline & Cases & percentage $\%$ & Cases & percentage $\%$ & Cases & percentage $\%$ \\
\hline Nulli Para & 180 & $50.0 \%$ & 19 & $46.3 \%$ & 199 & $49.6 \%$ \\
\hline Primi Para & 127 & $35.3 \%$ & 13 & $31.7 \%$ & 140 & $34.9 \%$ \\
\hline Second Para & 47 & $13.1 \%$ & 7 & $17.1 \%$ & 54 & $13.5 \%$ \\
\hline Multi Para & 6 & $1.7 \%$ & 2 & $4.9 \%$ & 8 & $2.0 \%$ \\
\hline Total & 360 & $100 \%$ & 41 & $100 \%$ & 401 & $100 \%$ \\
\hline \multicolumn{7}{|l|}{ Trimester } \\
\hline $1^{\text {st }}$ Trimester & 93 & $25.8 \%$ & 12 & $29.3 \%$ & 105 & $26.2 \%$ \\
\hline $2^{\text {nd }}$ Trimester & 147 & $40.8 \%$ & 8 & $19.5 \%$ & 155 & $38.7 \%$ \\
\hline $3^{\text {rd }}$ Trimester & 120 & $33.3 \%$ & 21 & $51.2 \%$ & 141 & $35.2 \%$ \\
\hline Total & 360 & $100.0 \%$ & 41 & $100 \%$ & 401 & $100 \%$ \\
\hline
\end{tabular}

Table no. 4 Distribution of Bacterial Isolates

\begin{tabular}{|l|c|c|c|}
\hline ISOLATE & CASES & PERCENTAGE & $95 \% \mathrm{CI}$ \\
\hline E.COLI & 31 & $75.61 \%$ & $59.70-87.64$ \\
\hline KLEBSIELLA & 6 & $14.63 \%$ & $5.56-29.17$ \\
\hline PSEUDOMONAS & 4 & $9.76 \%$ & $2.72-23.13$ \\
\hline TOTAL & 41 & $100 \%$ & \\
\hline
\end{tabular}

Table no 5. Maternal Outcome- According to Mode of Delivery

\begin{tabular}{|c|c|c|c|c|c|}
\hline \multirow{3}{*}{\multicolumn{2}{|c|}{ MATERNAL OUTCOME }} & \multicolumn{4}{|c|}{ Culture } \\
\hline & & \multicolumn{2}{|c|}{ Sterile } & \multicolumn{2}{|c|}{ Positive } \\
\hline & & Cases & Percentage $\%$ & Cases & Percentage $\%$ \\
\hline \multirow{2}{*}{ DELIVERED } & VAGINAL Delivery & 303 & $84.2 \%$ & 26 & $63.4 \%$ \\
\hline & Caesarean section & 24 & $6,7 \%$ & 8 & $19.5 \%$ \\
\hline \multicolumn{2}{|l|}{ ANC } & 8 & $2.2 \%$ & 0 & $0.0 \%$ \\
\hline \multicolumn{2}{|l|}{ LOST } & 25 & $6.9 \%$ & 7 & $17.1 \%$ \\
\hline
\end{tabular}

Table no 6 Maternal Complications 


\begin{tabular}{|l|c|c|c|c|}
\hline \multirow{2}{*}{ Maternal complications } & \multicolumn{3}{|c|}{ Culture } \\
\cline { 2 - 5 } & \multicolumn{3}{|c|}{ Sterile } & \multicolumn{2}{c|}{ Positive } \\
\cline { 2 - 5 } & CASES & PERCENTAGE \% & CASES & $\%$ \\
\hline Normal/no complication & 345 & $95.8 \%$ & 24 & $58.5 \%$ \\
\hline MODERATE ANAEMIA & 4 & $1.1 \%$ & 1 & $2.4 \%$ \\
\hline SEVERE ANAEMIA & 2 & $0.6 \%$ & 0 & $0.0 \%$ \\
\hline PRE-ECLAMPSIA & 5 & $1.4 \%$ & 8 & $19.5 \%$ \\
\hline ANAEMIA,PRE-ECLAMPSIA & 0 & $0.0 \%$ & 1 & $2.4 \%$ \\
\hline UTI & 2 & $0.6 \%$ & 8 & $19.5 \%$ \\
\hline Jaundice & 0 & $0.0 \%$ & 3 & $7.3 \%$ \\
\hline Abruptio-placentae & 2 & $0.6 \%$ & 0 & $0.0 \%$ \\
\hline
\end{tabular}

Table no 7 Fetal Outcome

\begin{tabular}{|c|c|c|c|c|}
\hline \multirow[t]{3}{*}{ OUTCOME } & \multicolumn{4}{|c|}{ Culture } \\
\hline & \multicolumn{2}{|c|}{ Sterile } & \multicolumn{2}{|c|}{ Positive } \\
\hline & CASES & $\%$ & CASES & $\%$ \\
\hline Normal/Healthy term baby & 329 & $98.2 \%$ & 18 & $52.9 \%$ \\
\hline Abortion & 0 & $0.0 \%$ & 2 & $5.9 \%$ \\
\hline Preterm & 2 & $0.6 \%$ & 6 & $17.6 \%$ \\
\hline LBW & 2 & $0.6 \%$ & 2 & $5.9 \%$ \\
\hline IUGR & 0 & $0.0 \%$ & 2 & $5.9 \%$ \\
\hline IUD & 0 & $0.0 \%$ & 2 & $5.9 \%$ \\
\hline EOS & 2 & $0.6 \%$ & 2 & $5.9 \%$ \\
\hline
\end{tabular}

\section{Discussion}

The urinary tract- so called "the problem tract" is second to respiratory tract in acquiring microbial infections especially in females and that so in pregnancy. Asymptomatic bacteriuria of pregnancy needs special considerations because of lack of symptoms and harmful consequences in pregnancy. All the pregnant women should be recommended to get screened for asymptomatic bacteriuria in their early pregnancy. The urine culture should be method of choice for screening and subsequently asymptomatic bacteriuria should be treated as per antimicrobial sensitivity pattern of the isolate to prevent maternal and perinatal morbidity. The pioneer in reporting incidence of asymptomatic bacteriuria was Kass ${ }^{1}$, overall the incidence in various Indian studies was found between $5 \%$ to $12 \%$ and in western studies the incidence ranges from 2 to $7 \%^{2}$. Sujata et al, $2013-2014^{3}$ found prevalence of asymptomatic bacteriuria $7.3 \%$. In present study the percentage of positive cases in age group <20,21-25,26$30,31-40$ years was $8.1 \%, 11.5 \%, 9.7 \%$ and $5.3 \%$ respectively, However this difference was not found statistically significant .Fatima et al,20012002 reported that asymptomatic bacteriuria have no association with age of the patients. In our study there was no significant difference in incidence of bacteriuria between primigravida and multigravida. Lavnya ${ }^{4}$ et al, found higher incidence in primigravida while study by Roy $^{5}$ et al, depicted higher incidence in multigravida. In present study higher incidence of bacteriuria was found in $3^{\text {rd }}$ trimester. R.J.G irishhbabu, R Shrikrishnan, and ST .Ramesh [2011], also observed that most cases of asymptomatic bacteriuria were found during $3^{\text {rd }}$ trimester of pregnancy ${ }^{6}$. The bacteria responsible for asymptomatic bacteriuria are of fecal origin which colonize the peri-urethral area. Gram negative 
bacteria are main causative agent. In different studies Lavnya et $\mathrm{al}^{4}$, Shamweel Ahmad et al, E.coli was found the commonest isolate, as was found in our study. Further follow up study was carried out for all patients included in study till delivery, out of 41 positive cases 2 cases were aborted spontaneously before 20 weeks of gestation. Caesarean section rate may increase in cases of asymptomatic bacteriuria, due to increase in rate of premature rupture of membranes subsequently drainage of liquor which lead to fetal distress, non progression of labour. In our study caesarean section rates were higher in positive cases (8/41), in comparision to sterile cases (24/360). Johnson and Kim et $\mathrm{al}^{11}$, reported that urinary tract infections, which occur during pregnancy increase caesarean section rate. In present study out of 360 sterile cases only 2 cases went in preterm labour while out of 41 positive cases 6 patients went in preterm labour. Schieve and collegues ${ }^{7}$, Nath et al, ${ }^{8}$ and Cochrane systemic review 2011 reported that asymptomatic bacteriuria increase the risk of pre- term delivery. In present study out of 360 sterile cases 5 cases had pre-eclampsia while out of 41 positive cases 8 cases had pre-eclampsia similarly in study by S.K.Roy et al, pre-eclamptic toxemia seen in $9.1 \%$ of bacteriuric group. In present study out of 41 positive cases $3(7.3 \%)$ cases developed UTI. Nicolle et $\mathrm{al}^{9}$, have reported $30 \%-40 \%$ of pregnant women with asymptomatic bacteriuria may develop symptomatic urinary tract infection. Out of 41 positive cases 8 [19.5\%] developed PROM. Fetal complications- In present study 6 cases had preterm delivery out of 41 cases, 2 babies born with LBW and 2babies born with intra uterine growth restriction and 2 cases developed early onset septicemia. Significantly higher rate of LBW babies was observed in cases withUTI [22.4\%], in comparison to those without UTI [7.7\%], in study conducted by G.Nath et $\mathrm{al}^{10}$. A study conducted in 2009 in the in the Soroka University Medical centre, Beer- Sheva,Israel reported that asymptomatic bacteriuria independently associated with prematurity,low birth weight and intrauterine growth restriction ${ }^{12}$. Therefore it is better to screen and treat the pregnant females with asymptomatic bacteriuria to avoid complications linked to it as it is rightly said that," prevention is better than cure".

\section{Conclusion}

Pregnancy associated bacteriuria is a common entity. The common pathogens involved are of fecal origin. Due to complications associated with asymptomatic bacteriuria in pregnancy, it should be made mandatory to screen every antenatal woman in early pregnancy for it. Urine culture is the ideal method for diagnosis .treatment with appropriate antibiotic therapy should be done in every positive case.

\section{References}

1. Kass EH.Bacteriuria in pregnancy and pyelonephritis of pregnany Arch Intern Med. 1960. 105:194-8.

2. Yashodhana P.Mthur R. Urinary tract infection in pregnancy. Indian J.med Res 1987:86.

3. Prevalence of asymptomatic bacteriuria and its antimicrobial susceptibility pattern among pregnant women attending the antenatal clinic at Kanpur,India J.Clen. Dergn Res 2014 Apr 8.

4. Lavanya SV,Jogalakshmi D. Asymptomatic bacteriuria in antenatal women . Ind.J. med .microbial 2002.

5. Roy SK Sinha GR Gudros M.A. a study of bateriuria in pregnancy. J.obslet Gynaecol India 1974.

6. RJ Girishbhu,R Shrikrishna,S.T. Ramesh, Internation journal of biological and medical research original article of asymptomatic bacteriuria in pregnancy. 2011

7. Williams obstetrics $23^{\text {rd }}$ edition page 1035 , Renal and urinary tract infections.

8. Nath G,Chaudhary M,Prakash J,et al. Urinary tract infection during pregnancy and fetal outcome. Indian $\mathbf{J}$ Med Microbial.1996;14;158-60. 
9. Nicolle LE,Bradley S,Colgan R,Rice JC,Schaeffer A,Hooton TM.Infectious Diseases Society of America guidelines for the diagnosis and treatment of aymptomatic bacteriuria in adults.Clin Inf Dis 2005;40;643-54.http://dx.doi.org/ 10.1086/427507.

10. Nath G Chaudhary et al Urinary tract infection during pregnancy and fetal outcome. Indian J med

11. Johnson EK,Kim ED. Urinary tract infections in pregnancy. Medscape; 2012.URL:overview (accessed 11april 2012).

12. Asymptomatic bacteriuria during pregnancy, Faculty of health science, Dept of Obstetrics \& Gynaecology, Soroka University medical centre Beer-sheva Israel,J matern Fetal Neonatal Med 2009 may 22. 